\title{
The Effect of Complement Depletion on
}

\section{Lung Clearance of Bacteria}

\author{
Gary N. Gross, Stanley R. Rehm, and Alan K. Pierce, The Pauline and Adolph \\ Weinberger Laboratory for Cardiopulmonary Research, Department of \\ Internal Medicine, University of Texas Southwestern Medical School, \\ Dallas, Texas 75235
}

\begin{abstract}
A B S TRACT We have investigated the effect of hypocomplementemia on early pulmonary clearance of four species of bacteria. The experiments were performed in an inbred animal model to minimize immunologic variability. Complement was depleted by cobra venom factor, and activity in serum was monitored with a phagocytic assay. Bacterial specific antibodies were examined by an indirect radioimmunoassay, and animals with high levels of activity were excluded from analysis.

$4 \mathrm{~h}$ after aerosolization with Streptococcus pneumoniae, complement-depleted animals had cleared only $75 \%$ of the initial number of organisms, whereas saline-treated controls cleared $91 \%(P<0.01)$. Aerosolization with Pseudomonas aeruginosa was followed at $4 \mathrm{~h}$ by a twofold greater growth of organisms in the complement-depleted animals (446\% of original deposition) as compared to the saline-treated controls (211\% of original deposition) $(P<0.02)$. Clearance of Klebsiella pneumoniae and Staphylococcus aureus were similar in complement-depleted animals and saline-treated controls.
\end{abstract}

These experiments suggest that hypocomplementemia predisposes to bacterial pneumonia and may explain the high incidence of pulmonary infections in patients having impaired complement activity. Our results further indicate that varying defense mechanisms may be involved with clearing the lung of differing bacterial species.

\section{INTRODUCTION}

The necessity of a functional complement system in host defense against bacteria has been inferred from the increased prevalence of bacterial respiratory infec-

Dr. Rehm is a Postdoctoral Research Fellow sponsored by the American Lung Association of Texas.

Received for publication 25 August 1977 and in revised form 13 March 1978. tions in persons with diseases associated with complement disorders. Additionally, in vitro studies have demonstrated complement's participation in phagocytosis and killing of bacteria (1-3), and increased mortality of complement-depleted mice after intraperitoneal inoculation with pneumococci has been demonstrated (4). The role of complement in pulmonary defense against bacteria has not been studied.

In the present study we have investigated the importance of an intact complement system for the early pulmonary clearance of organisms frequently associated with human pneumonia. To minimize immunologic variability the experiments were performed in inbred mice. All animals were screened for preexisting bacterial specific antibodies by a radioimmunoassay, and animals with elevated antibody levels were excluded. Complement depletion was achieved with cobra venom factor $(\mathrm{CoF})^{1}(5,6)$. Our data indicate complement to be necessary for optimal pulmonary clearance of Streptococcus pneumoniae and Pseudomonas aeruginosa, but not for Klebsiella pneumoniae or Staphylococcus aureus.

\section{METHODS}

Female Balb/c mice weighing 18-20 g (Charles River Breeding Laboratories, Wilmington, Mass.) were used. This inbred strain, in which complement depletion with $\mathrm{CoF}$ has been studied (6), was chosen to minimize immunologic variability among animals.

Bacteriology. S. pneumoniae, $P$. aeruginosa, and $K$. pneumoniae (originally obtained from clinical isolates), and $S$. aureus FDA 209 were used. The pneumococci and pseudomonads were passed on blood agar plates three times a week and the pneumococci were passed through mice at least once a month to maintain virulence. Other bacteria were maintained on trypticase soy agar slants with monthly transfer. Before aerosolization, bacteria were grown in brain heart infusion broth (S. pneumoniae and $P$. aeruginosa) or trypticase

\footnotetext{
${ }^{1}$ Abbreviations used in this paper: CFU, colony forming units; CoF, cobra venom factor; PBS, phosphate-buffered saline.
} 
soy broth (K. pneumoniae and $S$. aureus) for $18 \mathrm{~h}$. Bacteria then were washed twice in sterile saline and placed in a Collison nebulizer. Aliquots of this bacterial slurry were taken before each aerosol period and quantitated by serial 10-fold dilutions.

Antibody assay. An indrect radioimmunoassay to determine relative amounts of bacterial specific immunoglobulin was developed. ${ }^{2}$ Briefly, the IgG fraction of goat antimouse immunoglobulin (Cappel Laboratory, Cochranville, Pa.) was labeled with $\mathbf{N a}^{125}$ I (Amersham/Searle Corp., Arlington Heights, Ill.) by a modified lactoperoxidase technique (7). Bacteria from $18 \mathrm{~h}$ cultures were washed twice in phosphatebuffered saline (PBS), pH 7.2, at 2,600 $\mathrm{g}$ for $15 \mathrm{~min}$. These washed bacteria were resuspended in $0.3 \%$ formalin in PBS and remained at room temperature for $24 \mathrm{~h}$. The formalinkilled bacteria $w$ : e washed twice and resuspended in PBS to a final concen ion of $\cong 10^{8}$ organisms $/ \mathrm{ml}$ with previously determined optic i density correlations.

All assays were performed in triplicate by incubating $0.5 \mathrm{ml}$ of formalin-killed bacterial suspension with $10 \mu \mathrm{l}$ of mouse serum at $22^{\circ} \mathrm{C}$ for 30 min. After incubation each sample was washed three times at $766 \mathrm{~g}$ for $8 \mathrm{~min}$ at room temperature in PBS with a bovine serum albumin carrier $(1 \mathrm{mg} / \mathrm{ml})$. After the final wash, the bacterial pellet was resuspended in $0.5 \mathrm{ml}$ PBS, and $10 \mu \mathrm{l}\left(\cong 50 \mu \mathrm{g}\right.$ ) of ${ }^{125}$ I-goat antimouse immunoglobulin was added and the tube gently shaken. This mixture was incubated for $30 \mathrm{~min}$ at room temperature and washed three times in PBS as described. The final suspension of bacteria was collected over a filter $(0.45 \mu \mathrm{m}$ Millipore type HA, Millipore Corp., Bedford, Mass.) above a vacuum apparatus. The filters were then placed in $12 \times 75-\mathrm{mm}$ plastic tubes (Falcon Plastics, Div. of BioQuest, Oxnard, Calif.) for counting in an automatic gamma counter (G. D. Searle \& Co., Chicago, Ill., model 1195).

A small group of mice was intravenously immunized with $0.1 \mathrm{ml}$ of a suspension of formalin-killed organisms $\left(10^{8} / \mathrm{ml}\right)$. These animals were reinjected $1 \mathrm{wk}$ later and bled for antibody titers $1 \mathrm{wk}$ after the second injection. Separate groups of animals were used for each of the bacterial species studied. Controls of sera without bacteria and bacteria without sera were run with each antibody screening assay. Sera from all experimental animals were obtained 4 days before aerosolization and stored at $-20^{\circ} \mathrm{C}$.

Complement assay. Complement depletion was achieved by the use of CoF as previously described by others (4-6). CoF (Cordis Laboratories, Inc., Miami, Fla., lot no. 80696) was assayed for anticomplementary activity on human serum (30 $\mathrm{U} \mathrm{CoF}$ incubated with $0.3 \mathrm{ml}$ of $1: 10$ serum at $30^{\circ} \mathrm{C}$ for $60 \mathrm{~min}$ ) and found to be active at the potency stated by the manufacturer. Each mouse received $250 \mathrm{U} / \mathrm{kg}$ of $\mathrm{CoF}$ intraperitoneally in 4 equally divided doses in the 24 -h period before the aerosol challenge. Control animals received similarly timed injections of normal saline. In preliminary experiments, we demonstrated reduced opsonic activity of mouse serum for at least $5 \mathrm{~h}$ after the fourth injection.

Complement activity was assayed by measuring phagocytic activity (attributable to the complement system) in a modification of the in vitro test described by Jasin et al. (8). This assay measures the opsonic activity of serum for a bacterium which activates complement in the absence of specific antibody (Escherichia coli 075). Bacterial suspension is incubated with polymorphonuclear leukocytes. In the presence of serum with complement activity, phagocytosis will occur and fewer numbers of viable bacteria will result than similarly incubated

${ }^{2}$ Gross, G. N., and D. A. Hart. 1977. A method for detection of class specific antibodies to bacteria in small amounts of serum. Manuscript in preparation. bacteria and cells in the absence of a complement source. Thus, low colony counts are obtained when complement is present to opsonize, but high colony counts are an indication of the absence of complement. Polymorphonuclear leukocytes were obtained from normal human blood, and E. coli 075 were grown and processed as previously described (8). $25 \mu \mathrm{l}$ of fresh normal mouse serum or experimental mouse serum stored at $-70^{\circ} \mathrm{C}, 250 \mu \mathrm{l}$ of washed leukocytes, $175 \mu \mathrm{l}$ of Hanks' solution containing $0.1 \%$ gelatin, and $50 \mu$ l of diluted bacterial suspension were added in duplicate to $1.5 \mathrm{ml}$ polypropylene tubes (Brinkmann Instruments, Westbury, N. Y.). The tubes were then incubated at $37^{\circ} \mathrm{C}$ for $2 \mathrm{~h}$ rotating end over end at 12 inversions/min. After this incubation, tubes were spun at $150 \mathrm{~g}$ for $10 \mathrm{~min}$ to collect the cells at the bottom while leaving the bacteria in suspension. An aliquot was taken for serial 10-fold dilutions on trypticase soy agar plates. Bacterial colonies were counted after overnight incubation at $37^{\circ} \mathrm{C}$.

The phagocytic assay required large numbers of normal human leukocytes and was necessarily performed on different days for animals aerosolized with any one bacterial species. Equal numbers of saline- and cobra venom-treated animals were included in each day's assay. Additionally, normal mouse serum and heat-inactivated serum $\left(56^{\circ} \mathrm{C}, 60 \mathrm{~min}\right)$ were included with each day's assay for comparison with experimental groups. These controls were necessary because of the differing phagocyte:bacteria ratios and consequent variability of numbers of colony forming units (CFU) on different days.

Clearance. Aerosolization was performed in a Henderson aerosol chamber with a previously described exposure system for 66 mice (9). After a 30-min aerosol period, animals were removed from the chamber and equal groups of treated (CoF) and control (saline) animals were killed immediately and after $4 \mathrm{~h}$. Each animal was bled just before sacrifice, and the serum was stored at $-70^{\circ} \mathrm{C}$ for later assay of complement activity. After sacrifice, the chest was aseptically opened and the right lung placed in a sterile glass flask containing $4 \mathrm{ml}$ sterile distilled water. The lung was ground with a tissue homogenizer (Virtis 45, The Virtis Co., Gardiner, N. Y.) followed by further homogenization (Broeck tissue grinder, Corning Glass Works, Corning, N. Y.) to insure complete rupture of all cells. Cell disruption was insured by trypan blue staining of the homogenate, and no intact cells were found.

Statistical analysis. Statistical analysis was performed by the Mann-Whitney $U$ test for nonparametric analysis (10). A probability value of less than 0.05 was considered significant.

\section{RESULTS}

Antibodies. In preliminary experiments serum from germ-free mice was found to be similar in antibody concentration to serum obtained from routinely handled Balb/c mice. These base-line counts ("Experimental" in Table I) were considered to be indicative of no antibody or low antibody levels. No experimental animal had antibody concentrations as high as the immunized controls. In the pneumococcal aerosolized group, two animals had antibody concentrations greater than the $95 \%$ confidence level of the group $(\bar{M}+1.645$ SD). These animals were not included in further analysis. Four animals in the klebsiella group had elevated antibody concentrations and were not utilized. No animal in the pseudomonas group was excluded by this criterion. 
TABLE I

Antibody Concentrations

\begin{tabular}{|c|c|c|c|c|}
\hline & \multicolumn{2}{|c|}{ Experimental } & \multicolumn{2}{|r|}{ Immunized } \\
\hline & No. animals & Mean $\quad( \pm$ SEM $)$ & No. animals & $( \pm$ SEM $)$ \\
\hline & \multicolumn{2}{|r|}{$c p m^{*}$} & \multicolumn{2}{|r|}{$c p m^{*}$} \\
\hline S. pneumoniae & 61 & $28,417( \pm 1,403)$ & 3 & $205,954( \pm 23,498)$ \\
\hline P. aeruginosa & 60 & $42,556( \pm 1,953)$ & 3 & $140,618( \pm 5,232)$ \\
\hline K. pneumoniae & 62 & $54,131( \pm 3,461)$ & 4 & $262,734( \pm 30,477)$ \\
\hline
\end{tabular}

* cpm indicates counts per minute of ${ }^{125}$ I-antimouse immunoglobulin.

$90 \%$ of all $S$. aureus strains are known to contain Protein A (11). Our antibody assay indicated that $S$. aureus FDA 209 contains Protein A; therefore, we were unable to measure specific antibody concentrations. Because this strain of Staphylococcus has been used in clearance models by other investigators $(12,13)$, we chose to use it for comparison despite this disadvantage.

Complement. Animals were judged not complement depleted if they fell outside the $95 \%$ confidence level of the group of CoF-treated animals, or if they did not have five times as many CFU as the average of the simultaneously assayed control group. By these criteria, one Klebsiella- and five pneumococcus-aerosolized animals were not complement depleted and were eliminated from analysis.

For each day's assay, the differences in numbers of CFU in the CoF and control groups were clearly different with no overlap. The average number of CFU in the saline group correlated with the normal mouse serum control and the average CoF-treated group with the heated serum control. The results of one day's assay for each bacterial species are shown in Table II.

Bacterial clearance. Deposition in the lung of the different bacteria varied as a consequence of differing concentrations of bacteria in the Collison nebulizer (Table III). Although there was a tendency toward less initial deposition in the CoF-treated groups, these differences were not statistically significant.

The clearance of $S$. pneumoniae was significantly depressed in the complement-depleted group as compared to the normal controls (Fig. 1). The saline controls cleared $91 \%$ of the initially deposited bacteria whereas the complement-depleted animals cleared only $75 \%$.

In those animals aerosolized with $P$. aeruginosa, there was growth of bacteria in the lung during the 4-h time period. In the complement-depleted group the multiplication was significantly greater (446\%) than in the saline group (211\%).

In the $K$. pneumoniae and $S$. aureus aerosolized groups, there were no significant differences in the clearance of bacteria in complement-depleted animals compared to normal animals at the 4-h time period (Table IV).

\section{DISCUSSION}

Clinical data suggest the importance of the complement system in defense against bacteria. Diseases associated with depressed complement factors, such as systemic lupus erythematosis and sickle-cell disease, have a high incidence of bacterial infections, however, other host factors may also be altered $(8,14)$.

TABLE II

Results of Phagocytic Assay for Complement Activity

\begin{tabular}{|c|c|c|c|c|c|}
\hline \multirow[b]{2}{*}{ Bacteria aerosolized } & \multirow{2}{*}{$\begin{array}{c}\text { No. animals } \\
\text { in each } \\
\text { experimental } \\
\text { group }\end{array}$} & $\begin{array}{c}\text { Serum of } \\
\text { cobra factor- } \\
\text { treated animals }\end{array}$ & \multirow{2}{*}{$\begin{array}{l}\text { Heated } \\
\text { serum } \\
\text { control }\end{array}$} & \multirow{2}{*}{$\begin{array}{c}\begin{array}{c}\text { Serum of } \\
\text { saline-treated } \\
\text { animals }\end{array} \\
\text { Mean }( \pm \mathrm{SD})\end{array}$} & \multirow{2}{*}{$\begin{array}{l}\text { Normal } \\
\text { serum } \\
\text { control }\end{array}$} \\
\hline & & Mean $( \pm \mathrm{SD})$ & & & \\
\hline & & $C F U^{*}$ & $C F U^{*}$ & $\mathrm{CFU}^{*}$ & $\mathrm{CFU}^{*}$ \\
\hline S. pneumoniae & 8 & $390( \pm 65)$ & 409 & $2.4( \pm 2.4)$ & 1 \\
\hline P. aeruginosa & 8 & $314( \pm 49)$ & 320 & $1.6( \pm 0.6)$ & 1 \\
\hline K. pneumoniae & 10 & $189( \pm 24)$ & 192 & $6.1( \pm 2.2)$ & 2 \\
\hline S. aureus & 10 & $483( \pm 143)$ & 431 & $1.2( \pm 0.9)$ & 1 \\
\hline
\end{tabular}

* CFU represents the number of $E$. coli colonies counted on trypticase soy plate. 
TABLE III

Relationship of Bacterial Slurry and Initial Deposition of Bacteria

\begin{tabular}{lcccc}
\hline & & \multicolumn{3}{c}{ Initial deposition } \\
\cline { 3 - 5 } & Collison nebulizer & Control & Saline & \multicolumn{1}{c}{ CoF } \\
\hline & $C F U^{*} \times 10^{\%} / \mathrm{ml}$ & $C F U^{*}( \pm S E M) \times 10^{3}$ & & $C F U^{*}( \pm S E M) \times 10^{3}$ \\
S. pneumoniae & & $36.7( \pm 3.8)$ & $P>0.10$ & $28.2( \pm 3.7)$ \\
$P$. aeruginosa & 0.64 & $118.7( \pm 7.6)$ & $P>0.10$ & $101.7( \pm 6.5)$ \\
K. pneumoniae & 5.7 & $89.7( \pm 7.6)$ & $P>0.20$ & $86.3( \pm 10.9)$ \\
S. aureus & 4.7 & $635.6( \pm 29.1)$ & $P>0.20$ & $575.3( \pm 41.8)$ \\
\hline
\end{tabular}

* CFU represents the number of bacterial colonies on the plate multiplied by the dilution factor of that plate.

A recent investigation of immunologic events associated with pneumococcal pneumonia found a depression of complement components in all patients dying of their disease, whereas patients not dying had normal or elevated complement levels within the first week of hospitalization (15). A causal relationship between complement depression and infection could not be made because complement levels before the onset of infection were not available. In the clinical setting of specific C3 deficiency, an increased incidence of bacterial respiratory infection has been reported, but too few cases exist for meaningful analysis of pathogenic mechanisms $(16,17)$.

In vitro and in vivo models have been used to analyze the role of complement in bacterial defense (18-21).

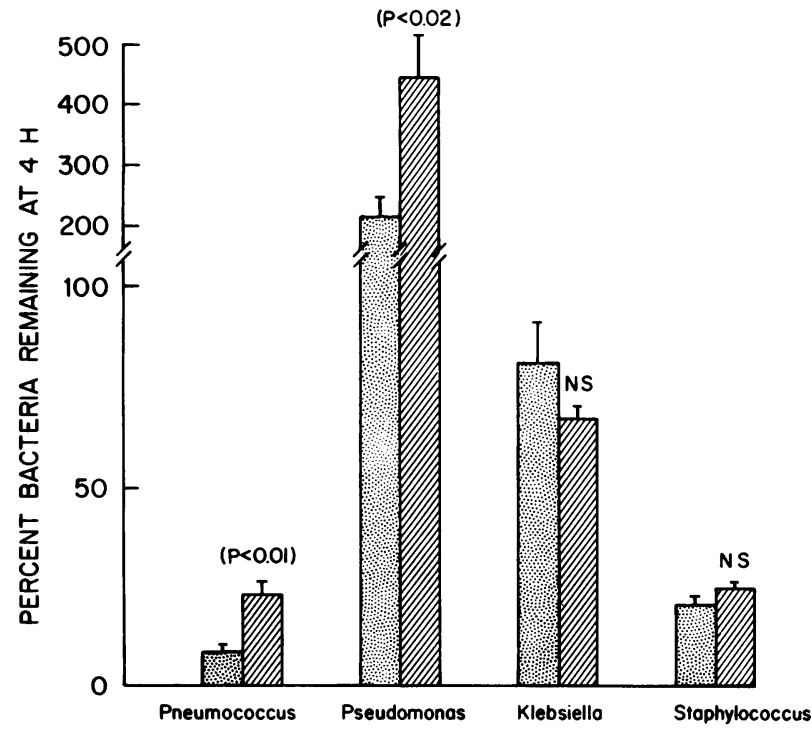

FIgURE 1 Percent of original bacterial deposition in mouse lung after $4 \mathrm{~h}$. Stippled bars represent control animals and cross-hatched bars represent complement-depleted animals. Significant differences in clearance are seen after aerosolization of pneumococcus and pseudomonas organisms, but not after Klebsiella or Staphylococcus.
Jeter's sytem, employing human peripheral leukocytes in the presence of type-specific antipneumococcal antisera showed inhibition of phagocytosis when complement activity was depressed (21). Winkelstein et al. have demonstrated the importance of $\mathrm{C} 3$ in host defense against intraperitoneally injected pneumococci in genetically C5-deficient AKR/J mice (4). These animals succumbed more readily to the pneumococcal infection after complement depletion by $\mathrm{CoF}$, indicating a role for complement components preceding C5, presumably C3. The inherent disadvantage in these previously reported experiments in examining pulmonary defense mechanisms is that they were not performed in the complicated milieu of the respiratory tract.

We utilized an animal model which directly reflects clearance of bacteria in the lung (22). This model examines an early phase of bacterial lung clearance and has previously been used to assess the effects of other states predisposing to human pneumonia (12). This

TABLE IV

Percent Bacteria Remaining 4 h after Aerosol

\begin{tabular}{|c|c|c|}
\hline & Saline-treated & Complement-depleted \\
\hline \multicolumn{3}{|l|}{ S. pneumoniae } \\
\hline Mean $( \pm$ SEM $)$ & $8.7( \pm 1.4)$ & $25.1( \pm 3.8)^{*}$ \\
\hline $\mathrm{N}_{0} / \mathrm{N}_{4}$ & $15 / 12$ & $14 / 12$ \\
\hline \multicolumn{3}{|l|}{ P. aeruginosa } \\
\hline Mean $( \pm$ SEM $)$ & $211.1( \pm 28.2)$ & $446.3( \pm 72.9) \ddagger$ \\
\hline $\mathrm{N}_{0} / \mathrm{N}_{4}$ & $16 / 13$ & $18 / 15$ \\
\hline \multicolumn{3}{|l|}{ K. pneumoniae } \\
\hline Mean $( \pm$ SEM $)$ & $81.5( \pm 10.5)$ & $67.2( \pm 3.1)$ \\
\hline $\mathrm{N}_{0} / \mathrm{N}_{4}$ & $14 / 13$ & $15 / 16$ \\
\hline \multicolumn{3}{|l|}{ S. aureus } \\
\hline Mean $( \pm$ SEM) & $20.6( \pm 2.3)$ & $24.6( \pm 1.3)$ \\
\hline $\mathrm{N}_{0} / \mathrm{N}_{4}$ & $17 / 16$ & $17 / 15$ \\
\hline
\end{tabular}

$\mathrm{N}_{0} / \mathrm{N}_{4}=$ no. of animals sacrificed at $0 \mathrm{~h} / \mathrm{no}$. of animals sacrificed at $4 \mathrm{~h}$.

$* P<0.01$.

$\ddagger P<0.02$. 
early bacteria-to-phagocyte interaction is felt to be an important factor in determining whether an invading organism will subsequently multiply within the lungs or be easily eliminated. An inbred mouse strain was used to reduce variability of complement component levels, the control of which is associated with histocompatability genes (23). We further insured comparability of animals by eliminating those with preexisting bacterial specific antibodies. Such antibodies could have been induced by direct exposure to bacteria of similar species or to antigens having shared antigenicity $(24,25)$.

$\mathrm{CoF}$ activates the third component of complement and the complement cascade with minimal alteration of other host factors (26). The dosage schedule that we employed has been shown to effectively deplete complement components for several days (5). Complement opsonic activity may return to normal at a time when immunoreactive components are still depressed (4). To insure a decrease in complement activity rather than only a depression of immunoreactive components, we performed assays to determine serum opsonic activity after each aerosol challenge.

Our results demonstrate a requirement for an intact complement system for optimal early pulmonary clearance of some but not all bacteria. Because it is unlikely that direct lysis of bacteria by complement in the absence of specific antibacterial antibodies is a significant antibacterial factor, its primary role is likely one of augmenting bacteria-phagocyte interaction (27). Depending on the bacterial species, both alveolar macrophages and polymorphonuclear leukocytes have been observed histologically to participate in early bacterial defense of the lung (28-30). Alveolar macrophages have been shown to have receptors for complement components and may require this opsonin for optimal phagocytic action (31). Similarly, polymorphonuclear leukocytes have such receptors and also are recruited in part by complement chemotactic factors $(32,33)$.

These data indicate that complement depletion per se may increase susceptibility to pulmonary infection with $S$. pneumoniae and $P$. aeruginosa. The experiments thus provide evidence for a causative mechanism for previously observed clinical findings.

\section{ACKNOWLEDGMENTS}

The authors wish to thank Ms. Kim Jones for her technical assistance and Mrs. Nettie Campbell for preparation of this manuscript.

This investigation was supported in part by grant HL 21827 from the National Heart, Lung and Blood Institutes and the Board of Regents grant no. 14303.

\section{REFERENCES}

1. Johnston, Jr., R. B., M. R. Klemperer, C. A. Alper, and F. S. Rosen. 1969. The enhancement of bacterial phagocytosis by serum. J. Exp. Med. 129: 1275-1290.
2. Young, L. S., and D. Armstrong. 1972. Human immunity to Pseudomonas aeruginosa. I. In-vitro interaction of bacteria, polymorphonuclear leukocytes, and serum factors. J. Infect. Dis. 126: 257-276.

3. Shin, H. S., M. R. Smith, and W. B. Wood, Jr. 1969. Heat labile opsonins to pneumococcus. II. Involvement of C3 and C5. J. Exp. Med. 130: 1229-1241.

4. Winkelstein, J. A., M. R. Smith, and H. S. Shin. 1975. The role of $\mathrm{C} 3$ as an opsonin in the early stages of infection. Proc. Soc. Exp. Biol. Med. 149: 397-401.

5. Cochrane, C. G., H. M. Müller-Eberhard, and B. S. Aikin. 1970. Depletion of plasma complement in vivo by a protein of cobra venom: its effect of various immunologic reactions. J. Immunol. 105: 55-69.

6. Pepys, M. B. 1975. Studies in vivo of cobra factor and murine C3. Immunology. 28: 369-377.

7. Baur, S., E. S. Vitetta, C. J. Sherr, I. Schenkein, and J. W. Uhr. 1971. Isolation of heavy and light chains of immunoglobulin from the surfaces of lymphoid cells. J. Immunol. 106: $1133-1135$.

8. Jasin, H. E., J. H. Orozco, and M. Ziff. 1974. Serum heatlabile opsonins in systemic lupus erythematosus. J. Clin. Invest. 53: 343-353.

9. Southern, Jr., P. M., A. K. Pierce, and J. P. Sanford. 1968. Exposure chamber for 66 mice suitable for use with the Henderson aerosol apparatus. Appl. Microbiol. 16: 540542.

10. Wilks, S. S. 1962. Mathematical Statistics. R. A. Bradley, J. S. Hunter, D. G. Kendall, G. S. Wilson, editors. John Wiley \& Sons, Inc., New York.

11. Forsgren, A., and K. Nordström. 1974. Protein A from Staphylococcus aureus: the biological significance of its reaction with IgG. Ann. N. Y. Acad. Sci. 236: 252-266.

12. Laurenzi, G. A., L. Berman, M. First, and E. H. Kass. 1964. A quantitative study of the deposition and clearance of bacteria in the murine lung.J. Clin. Invest. 43: 759-768.

13. Jakab, G. J., and G. M. Green. 1972. The effect of Sendai virus infection on bactericidal and transport mechanisms of the murine lung. J. Clin. Invest. 51: 1989-1998.

14. Johnston, Jr., R. B., S. L. Newman, and A. G. Struth. 1973. An abnormality of the alternate pathway of complement activation in sickle-cell disease. N. Engl. J. Med. 288: $803-808$.

15. Dee, T. H., G. Schiffman, M. I. Sottile, and M. W. Rytel. 1977. Immunologic studies in pneumococcal disease. J. Lab. Clin. Med. 89: 1198-1207.

16. Alper, C. A., N. Abramson, R. B. Johnston, Jr., J. H. Jandl, and F. S. Rosen. 1970. Increased susceptibility to infection associated with abnormalities of complement-mediated functions and of the third component of complement (C3). N. Engl. J. Med. 282: 349-354.

17. Ballow, M., J. E. Shira, L. Harden, S. Y. Yang, and N. K. Day. 1975. Complete absence of the third component of complement in man. J. Clin. Invest. 56: 703-710.

18. Ward, H. K., and J. F. Enders. 1933. An analysis of the opsonic and tropic action of normal and immune sera based on experiments with the pneumococcus. J. Exp. Med. 57: 527-547.

19. Smith, M. R., and W. B. Wood, Jr. 1969. Heat labile opsonins to pneumococcus. I. Participation of complement. J. Exp. Med. 130: 1209-1227.

20. Durack, D. T., and P. B. Beeson. 1977. Protective role of complement in experimental Escherichia coli endocarditis. Infect. Immun. 16: 213-217.

21. Jeter, W. S., A. P. McKee, and R. J. Mason. 1961. Inhibition of immune phagocytosis of Diplococcus pneumoniae by human neutrophiles with antibody against complement. J. Immunol. 86: 386-391. 
22. Jay, S. J., W. G. Johanson, Jr., A. K. Pierce, and J. S. Reisch. 1976. Determinants of lung bacterial clearance in normal mice. J. Clin. Invest. 57: 811-817.

23. Goldman, M. B., and J. N. Goldman. 1976. Relationship of functional levels of early components of complement to the H-2 complex of mice. J. Immunol. 117: 1584-1588.

24. Schneerson, R., and J. B. Robbins. 1975. Induction of serum Haemophilus influenzae type B capsular antibodies in adult volunteers fed cross-reacting Escherichia coli 075:K100:H5. N. Engl. J. Med. 292: 1093-1096.

25. Springer, G. F., and R. E. Horton. 1969. Blood group isoantibody stimulation in man by feeding blood groupactive bacteria. J. Clin. Invest. 48: 1280-1291.

26. Henson, P. M., and C. G. Cochrane. 1975. The effect of complement depletion on experimental tissue injury. Ann. N. Y. Acad. Sci. 256: 426-440.

27. Eisen, H. N. 1974. Complement. In Immunology. Herman N. Eisen, editor. Harper \& Row Publishers, Hagerstown, Md. 512-525.
28. Loosli, C. G., and R. F. Baker. 1962. Acute experimental pneumococcal (Type I) pneumonia in the mouse: the migration of leukocytes from the pulmonary capillaries into the alveolar spaces as revealed by the electron microscope. Trans. Am. Clin. Climatol. Assoc. 74: 15-28.

29. Goldstein, E., W. Lippert, and D. Warshauer. 1974. Pulmonary alveolar macrophage. Defender against bacterial infection of the lung. J. Clin. Invest. 54: 519-528.

30. Pierce, A. K., R. C. Reynolds, and G. D. Harris. 1977. Leukocytic response to inhaled bacteria. Am. Rev. Respir. Dis. 116: 679-684.

31. Reynolds, H. Y., J. P. Atkinson, H. H. Newball, and M. M. Frank. 1975. Receptors for immunoglobulin and complement on human alveolar macrophages. J. Immunol. 114: 1813-1819.

32. Lay, W. H., and V. Nussenzweig. 1968. Receptors for complement on leukocytes. J. Exp. Med. 128: 991-1009.

33. Sorkin, E., V. J. Stecher, and J. F. Borel. 1970. Chemotaxis of leucocytes and inflammation. Ser. Haematol. 111: $131-162$. 